\title{
Rancang Bangun Aplikasi Pelelangan Online (E-Auction) Berbasis Perangkat Bergerak Android
}

\author{
Andre Setiawan, Rully Soelaiman, dan Rizky Januar Akbar \\ Departemen Teknik Informatika, Fakultas Teknologi Informasi, Institut Teknologi Sepuluh Nopember (ITS) \\ e-mail: rully@if.its.ac.id
}

\begin{abstract}
Abstrak-Kemajuan internet di Indonesia mengakibatkan berkembangnya industri $e$-commerce. Menjamurnya industri $e$ commerce semakin mempermudah masyarakat Indonesia untuk menjual. mencari dan membeli barang yang diinginkan. Salah satu jenis transaksi jual beli yang telah diketahui secara umum adalah transaksi lelang. Namun, banyak pengguna yang merasa tidak puas dengan sistem lelang online karena banyak hal, seperti yang dijabarkan pada paper "Online auction service failures in Taiwan: Typologies and recovery strategies" yang membahas mengenai kegagalan aplikasi lelang online berdasarkan survey pengguna di Taiwan. Berangkat dari masalah yang diangkat dari paper rujukan dan besarnya pengguna ponsel pintar Android di Indonesia, penulis mengembangkan aplikasi lelang online berbasis perangkat Android dengan fitur tambahan yang disarankan pada paper rujukan. Penulis juga mengalanisa UI-UX, fitur, dan alur kerja dari aplikasi Android milik e-commerce besar di Indonesia sehingga aplikasi yang dikembangkan dapat sesuai dengan alur jual beli online yang terjadi di Indonesia. Dengan aplikasi ini, diharapkan dapat meningkatkan peluang lelang online untuk bisa bersaing pada pasar e-commerce di Indonesia.
\end{abstract}

Kata Kunci-Lelang, e-commerce, marketplace.

\section{PENDAHULUAN}

$\mathrm{T}$ EKNOLOGI internet yang sedang berkembang di Indonesia saat ini membuat tumbuhnya berbagai $e$ commerce. E-commerce yang sedang tumbuh dan berkembang di Indonesia pun bervariasi pada berbagai niche yang disasar oleh pendirinya. Terdapat banyak sekali variasi e-commerce saat ini, diantaranya online marketplace, pembelian tiket pesawat dan hotel secara online, pembelian tiket kereta secara online, situs e-commerce iklan baris, dan masih banyak lagi. Namun, masih ada sebuah peluang e-commerce yang belum seberapa popular di Indonesia, yaitu sistem e-auction atau lelang secara online. Seperti yang kita ketahui, sistem lelang biasanya dilakukan oleh instansi-instansi tertentu dan terkesan masih sangat kaku. Lelang adalah penjualan barang secara terbuka untuk umum dengan penawaran harga secara tertulis dan lisan yang semakin meningkat atau menurun untuk mencapai harga tertinggi yang didahului dengan pengumuman lelang.

Pelelangan yang konvensional biasanya diadakan oleh sebuah perusahaan yang bergerak di bidang jual beli barang lelang di mana proses lelang diadakan di sebuah tempat sehingga konsumen atau penawar bisa berdatangan. Melalui studi ini, pelelangan barang dapat dilakukan secara online dan siapapun sebagai pengguna terdaftar dapat melelang barang apapun dan menawar barang apapun, layaknya sebuah pasar pelelangan, dan aplikasi ini akan dibuat dalam dua buah platform, yaitu web based dan mobile based. Selain itu, diharapkan aplikasi lelang online yang dibuat dapat menghapus stigma-stigma buruk yang melekat pada sistem lelang online yang sudah ada sebelumnya, seperti data yang tidak reliable, alur proses pelelangan yang tidak jelas dan membingungkan, produk yang didapatkan ternyata tidak sesuai dengan informasi pada saat produk dilelang (bad information), serta keamanan dari sistem lelang online yang kurang diperhatikan oleh pihak pengembang [1].

Hasil dari studi ini adalah berupa aplikasi sistem e-auction atau sistem pasar pelelangan online berbasis Android, dimana aplikasi ini dapat menambah user experience pengguna dan mempercepat kebutuhan pengguna untuk melakukan pelelangan, cukup melalui aplikasi Android, mengambil foto barang yang dilelang dan mengisi data-data, pengguna dapat langsung melelang barangnya. Dengan adanya aplikasi lelang online berbasis Android ini mempermudah dan mempercepat kebutuhan pengguna dalam melakukan lelang. Selain itu, melalui studi ini diharapkan dapat menghasilkan aplikasi reliable, jelas, dan aman.

\section{TINJAUAN PUSTAKA}

\section{A. Lelang}

Lelang adalah penjualan barang secara terbuka untuk umum dengan penawaran harga secara tertulis dan lisan yang semakin meningkat atau menurun untuk mencapai harga tertinggi yang didahului dengan pengumuman lelang. Lelang konvensional biasanya diadakan oleh sebuah perusahaan yang bergerak dibidang jual beli barang lelang dimana proses lelang diadakan di sebuah tempat sehingga konsumen atau penawar bisa berdatangan untuk menjadi peserta dari lelang tersebut. Di Indonesia, terdapat lembaga yang terkait dengan proses lelang, diantaranya Kantor Pelayanan Kekayaan Negara dan Lelang (KPKNL) dan balai lelang baik milik pemerintah maupun swasta [2] [3].

\section{B. Online Marketplace}

Marketplace (dalam bahasa Indonesia, pasar) adalah tempat bertemunya pembeli dan penjual untuk melakukan sebuah 
transaksi. Online marketplace sendiri merupakan sebuah platform untuk mempertemukan pembeli dan penjual secara daring. Online marketplace merupakan jenis e-commerce yang bersifat $\mathrm{C} 2 \mathrm{C}$ (consumer to consumer), dimana proses transaksi terjadi antara sesama individu yang memiliki akun di online marketplace tersebut. Setiap individu dapat bertindak sebagai penjual dan pembeli. Penyedia servis online marketplace dalam hal ini hanya bertindak sebagai perantara antar individu [4].

\section{Teknologi Terkait yang Pernah Dikembangkan}

Ebay merupakan sebuah aplikasi marketplace multinasional yang bergerak pada bidang consumer-to-consumer dan business-to-consumer. Selain melayani jual beli barang secara biasa, Ebay juga menyediakan fitur online auction atau lelang online. Saat ini, layanan Ebay tersedia di dalam platform web dan aplikasi mobile. Ebay beroperasi aktif di 30 negara [5]. Layanan yang diberikan oleh Ebay bersifat gratis untuk pembeli barang, namun bagi penjual terdapat biaya tambahan yang harus dibayarkan kepada Ebay ketika memasang barang jualan dan ketika ada barang yang terjual [6].

Kementerian Keuangan Republik Indonesia memiliki situs lelang milik negara [7]. Komoditas yang dilelang di situs lelang milik Kemenkeu RI adalah aset berupa tanah dan bangunan. Jenis lelang yang diakomodasi oleh situs lelang Kemenkeu RI adalah lelang eksekusi, lelang non-eksekusi, dan lelang sukarela.

\section{Analisis pada Studi Literatur}

Studi literatur yang dirujuk berjudul "Online auction service failures in Taiwan: Typologies and recovery strategies" membahas mengenai ketidakpuasan pengguna terhadap layanan e-commerce lelang online dengan melakukan survei terhadap pengguna dan menyimpulkan faktor-faktor ketidakpuasan pengguna hasil dari survei yang telah dilakukan. Studi literatur juga menyertakan solusi-solusi yang diberikan oleh pengguna aplikasi untuk memperbaiki kegagalan layanan yang ada. Berdasarkan hasil survei yang dilakukan oleh studi literatur, terdapat beberapa penyebab ketidakpuasan pengguna, diantaranya adalah informasi yang buruk mengenai barang yang dilelang sehingga tidak sesuai, kurangnya informasi terhadap penjual atau pelelang barang yang menyebabkan terjadinya fraud, dan problematika lainnya. Sementara itu, melakukan koreksi atas masalah yang terjadi dan memberikan kompensasi dapat mengembalikan tingkat kepuasan pengguna secara signifikan.

Studi literatur lain yang berjudul "The roles of players and reputation: Evidence from Ebay Online Auction" [8] menyimpulkan bahwa popularitas dan reputasi penjual adalah salah satu faktor penting bagi pembeli untuk bertransaksi. Semakin baik reputasi penjual akan membuat pembeli semakin percaya untuk melakukan transaksi dengan penjual. Melalui penjabaran ini, terlihat bahwa fitur popularitas dan reputasi memiliki peranan penting dalam aplikasi e-commerce untuk meminimalkan peluang terjadinya fraud yang berakibat kegagalan sistem.
Table 2

Categories of online auction service failures.

\begin{tabular}{lll}
\hline Type of service failure & No. & $\%$ \\
\hline Group 1. Service delivery system failures & & \\
Packaging problem & 207 & 23.9 \\
Slow or unavailable & 157 & 18.1 \\
Product defect & 142 & 16.4 \\
Out of stock & 61 & 7.1 \\
Bad information & 41 & 4.7 \\
Alterations and repairs & 18 & 2.1 \\
Hold disaster & 14 & 1.6 \\
Pricing failure & 10 & 1.2 \\
Policy failure & 10 & 1.2 \\
Subtotal, Group 1 & 660 & 76.3 \\
Group 2. Buyer needs and requests & & \\
Gap between expectation and perception & 83 & 9.6 \\
Size variation & 16 & 1.8 \\
Special order or request & 13 & 1.5 \\
Admitted buyer error & 3 & 0.3 \\
Subtotal, Group 2 & 115 & 13.2 \\
Group 3. Unprompted and unsolicited seller actions & & \\
Seller attention failures & 39 & 4.5 \\
Seller-created embarrassments & 22 & 2.5 \\
Seller fraud problem & 21 & 2.4 \\
Mischarged & 8 & 0.9 \\
Leak of personal data & 2 & 0.2 \\
Subtotal, Group 3 & 92 & 10.5 \\
Total & 867 & 100 \\
\hline
\end{tabular}

Gambar 1. Hasil Survey Insiden Kegagalan dalam Aplikasi Lelang Online yang Dimuat di Studi Literatur Rujukan

Table 4

Categories of online auction service recovery strategies.

\begin{tabular}{|c|c|c|c|c|c|}
\hline $\begin{array}{l}\text { Recovery } \\
\text { strategy }\end{array}$ & No. (\%) & $\begin{array}{l}\text { No. of } \\
\text { satisfactory } \\
\text { recovery }\end{array}$ & $\begin{array}{l}\text { No. of } \\
\text { dissatisfactory } \\
\text { recovery }\end{array}$ & $\begin{array}{l}\text { Satisfaction } \\
\text { with } \\
\text { recovery }\end{array}$ & $\begin{array}{l}\text { Retention } \\
\text { with } \\
\text { recovery }\end{array}$ \\
\hline Correction & $\begin{array}{l}280^{\mathrm{a}} \\
(32.3)^{\mathrm{b}}\end{array}$ & $\begin{array}{l}228^{\mathrm{a}} \\
(81.4)^{\mathrm{b}}\end{array}$ & $\begin{array}{l}52^{\mathrm{a}} \\
(18.6)^{\mathrm{b}}\end{array}$ & $\begin{array}{l}7.2^{\mathrm{c}} \\
(2.4)^{\mathrm{d}}\end{array}$ & $\begin{array}{l}6.6^{c} \\
(2.7)^{d}\end{array}$ \\
\hline Correction plus & $\begin{array}{l}82 \\
(9.5)\end{array}$ & $\begin{array}{l}77 \\
(93.9)\end{array}$ & $\begin{array}{l}5 \\
(6.1)\end{array}$ & $\begin{array}{l}7.7 \\
(2.1)\end{array}$ & $\begin{array}{l}7.6 \\
(2.5)\end{array}$ \\
\hline Discount & $\begin{array}{l}26 \\
(3.0)\end{array}$ & $\begin{array}{l}23 \\
(88.5)\end{array}$ & $\begin{array}{l}3 \\
(11.5)\end{array}$ & $\begin{array}{l}7.0 \\
(2.2)\end{array}$ & $\begin{array}{l}6.0 \\
(2.9)\end{array}$ \\
\hline Replacement & $\begin{array}{l}14 \\
(1.6)\end{array}$ & $\begin{array}{l}2 \\
(14.3)\end{array}$ & $\begin{array}{l}12 \\
(85.7)\end{array}$ & $\begin{array}{l}3.4 \\
(2.7)\end{array}$ & $\begin{array}{l}3.5 \\
(2.7)\end{array}$ \\
\hline Store credit & $\begin{array}{l}16 \\
(1.8)\end{array}$ & $\begin{array}{l}9 \\
(56.3)\end{array}$ & $\begin{array}{l}7 \\
(43.7)\end{array}$ & $\begin{array}{l}6.1 \\
(2.9)\end{array}$ & $\begin{array}{l}6.4 \\
(2.7)\end{array}$ \\
\hline Apology & $\begin{array}{l}54 \\
(6.2)\end{array}$ & $\begin{array}{l}20 \\
(37.0)\end{array}$ & $\begin{array}{l}34 \\
(63.0)\end{array}$ & $\begin{array}{l}3.7 \\
(2.6)\end{array}$ & $\begin{array}{l}3.4 \\
(2.6)\end{array}$ \\
\hline Refund & $\begin{array}{l}67 \\
(7.7)\end{array}$ & $\begin{array}{l}42 \\
(62.7)\end{array}$ & $\begin{array}{l}25 \\
(37.3)\end{array}$ & $\begin{array}{l}6.4 \\
(2.9)\end{array}$ & $\begin{array}{l}5.2 \\
(3.1)\end{array}$ \\
\hline $\begin{array}{l}\text { Unsatisfactory } \\
\text { correction }\end{array}$ & $\begin{array}{l}182 \\
(21.0)\end{array}$ & $\begin{array}{l}0 \\
(0)\end{array}$ & $\begin{array}{l}182 \\
(100.0)\end{array}$ & $\begin{array}{l}1.9 \\
(1.3)\end{array}$ & $\begin{array}{l}1.8 \\
(1.6)\end{array}$ \\
\hline $\begin{array}{l}\text { Failure } \\
\text { escalation }\end{array}$ & $\begin{array}{l}39 \\
(4.5)\end{array}$ & $\begin{array}{l}0 \\
(0)\end{array}$ & $\begin{array}{l}39 \\
(100)\end{array}$ & $\begin{array}{l}1.3 \\
(0.9)\end{array}$ & $\begin{array}{l}1.3 \\
(0.9)\end{array}$ \\
\hline Nothing & $\begin{array}{l}107 \\
(12.4)\end{array}$ & $\begin{array}{l}0 \\
(0)\end{array}$ & $\begin{array}{l}107 \\
(100)\end{array}$ & $\begin{array}{l}1.7 \\
(1.2)\end{array}$ & $\begin{array}{l}1.7 \\
(1.6)\end{array}$ \\
\hline Total & $\begin{array}{l}867 \\
(100)\end{array}$ & $\begin{array}{l}407 \\
(46.9)\end{array}$ & $\begin{array}{l}460 \\
(53.1)\end{array}$ & $\begin{array}{l}4.8 \\
(3.3)\end{array}$ & $\begin{array}{l}4.4 \\
(3.3)\end{array}$ \\
\hline
\end{tabular}

${ }^{\text {a }}$ Number.

b\%.

c Mean.

d Standard deviation.

Gambar 2. Hasil Survey terhadap Fasilitas Perbaikan pada Aplikasi Lelang Online

\section{E. Analisis Standar Pengembangan Perangkat Lunak}

Terdapat banyak aspek teknis yang harus diperhatikan untuk mengembangkan aplikasi yang memiliki kualitas baik. Pengembangan aplikasi harus merujuk pada alur proses dalam pengembangan perangkat lunak, sehingga proses pengembangan bisa lebih terkoordinasi dan perubahan dapat dilakukan dengan cepat dan efektif. 
Menurut Sommerville dalam bukunya yang berjudul Software Engineering edisi ke-9 [9], terdapat empat buah proses fundamental yang harus dilakukan dalam pengembangan perangkat lunak, diantaranya sebagai berikut:

1. Software specification

2. Software design and implementation

3. Software validation

4. Software evolution

Untuk menghasilkan aplikasi yang berkualitas, efisien, dan siap untuk dikembangkan lebih lanjut, maka setiap poin harus diperhatikan dalam pengembangan aplikasi.

\section{F. Analisis Standar Pengembangan Pengalaman Pengguna}

Kesuksesan sebuah aplikasi tidak hanya ditentukan dari fungsionalitas fitur dari aplikasi yang sudah dikembangkan, melainkan juga ditentukan dari user experience (UX) pada aplikasi tersebut. User experience yang baik dapat menyebabkan pengguna merasa nyaman ketika menggunakan aplikasi, dan berpotensi besar untuk menarik pengguna awal aplikasi menjadi pengguna tetap.

Berdasarkan salah satu sumber yang membahas mengenai user experience pada UXPlanet [10], terdapat beberapa poin penting yang harus diperhatikan, diantaranya:

1. Satu screen untuk satu tugas

2. Berikan sedikit space kosong pada tampilan

3. Navigasi menu yang jelas dan mudah diakses

4. Dapat dioperasikan dengan mudah menggunakan satu tangan

5. Konten harus ditayangkan dengan cepat

6. Gunakan push notification jika diperlukan

Dalam menghasilkan aplikasi yang memperhatikan detail dari user experience, menggunakan referensi dari aplikasiaplikasi lain adalah hal yang dapat dibenarkan.

\section{G. Analisis Proses Bisnis Aplikasi}

Pengembangan aplikasi harus memperhatikan proses bisnis dari aplikasi yang dikembangkan. Untuk mempermudah pengguna dalam memahami aplikasi saat menggunakan, diperlukan proses bisnis yang jelas dan tidak membingungkan. Menggunakan proses bisnis dari aplikasi-aplikasi e-commerce di Indonesia yang sudah ada maupun aplikasi serupa dapat mempermudah pengguna yang merupakan masyarakat Indonesia dalam menggunakan aplikasi karena sudah terlebih dahulu familiar dengan aplikasi $e$-commerce di Indonesia yang sudah pernah digunakan sebelumnya.

Proses bisnis aplikasi e-commerce secara umum adalah sebagai berikut:

1. Proses untuk mengelola data pribadi pengguna.

2. Proses untuk mengelola barang yang dijual pengguna.

3. Proses untuk melakukan aktivitas transaksi.

4. Proses untuk melakukan aktivitas pengguna.

\section{H. Analisis Potensi Aplikasi}

Penulis sempat membaca artikel yang dimuat pada situs TechInAsia [11] yang menyatakan bahwa terdapat trend baru di Singapura, yaitu lelang online melalui fitur Facebook Live. Menurut penulis, hal ini menunjukkan bahwa potensi pasar dari lelang online masih memiliki peminat yang cukup tinggi.

\section{Analisis Potensi Pasar dari Sistem Operasi Android}

Pasar ponsel pintar yang beroperasi dengan sistem operasi Android adalah yang tertinggi di dunia. Sebanyak 432 juta ponsel pintar yang terjual per kuartal-4 tahun 2016, 352 juta diantaranya $(81,7 \%)$ berjalan dengan sistem operasi Android [12]. Sementara, Android menguasai $86,1 \%$ pasar ponsel pintar sepanjang masa, diikuti Apple iOS dengan 13,7\% [13].

\section{ANALISIS DAN PERANCANGAN}

\section{A. Analisa Kebutuhan}

Terdapat 4 (empat) kebutuhan utama yang harus dipenuhi untuk membuat aplikasi marketplace yang familiar bagi pengguna. Empat kebutuhan utama tersebut diantaranya adalah sebagai berikut:

1. Aplikasi memungkinkan pengguna untuk mengelola data diri miliknya;

2. Aplikasi memungkinkan pengguna untuk mengelola barang-barang miliknya;

3. Aplikasi memungkinkan pengguna untuk melakukan aktivitas transaksi utama yang terjadi; dan

4. Aplikasi memungkinkan pengguna untuk menjalankan aktivitas pendukung lain yang mendukung produktivitas pengguna;

\section{B. Deskripsi Aplikasi}

Berdasarkan permasalahan yang diangkat dan studi literatur yang digunakan dan adanya potensi yang cukup besar, salah satu solusi adalah mengembangkan aplikasi e-commerce berbasis lelang di Indonesia dengan user experience yang menarik dan alur bisnis seperti layanan e-commerce yang umum digunakan oleh masyarakat Indonesia. Aplikasi akan berjalan di sistem operasi Android. Pada Gambar 3 adalah Diagram Berikut ini adalah kebutuhan fungsional dari aplikasi yang dikembangkan.

1. Menangani pengelolaan profil pengguna.

2. Menangani pengelolaan barang-barang lelang.

3. Menangani pengelolaan aktivitas saat lelang berlangsung, meliputi memasukkan penawaran, memilih tawaran sebagai pemenang, membatalkan tawaran dari penawar, melakukan blok pada penawar, dan membatalkan lelang.

4. Menjalankan rangkaian aktivitas pengguna, seperti melakukan pemberian ulasan dan melihat daftar ulasan, melakukan pencarian barang, melihat daftar dan detail riwayat penawaran, menerima notifikasi masuk, berkirim pesan singkat, dan mengelola barang favorit. 


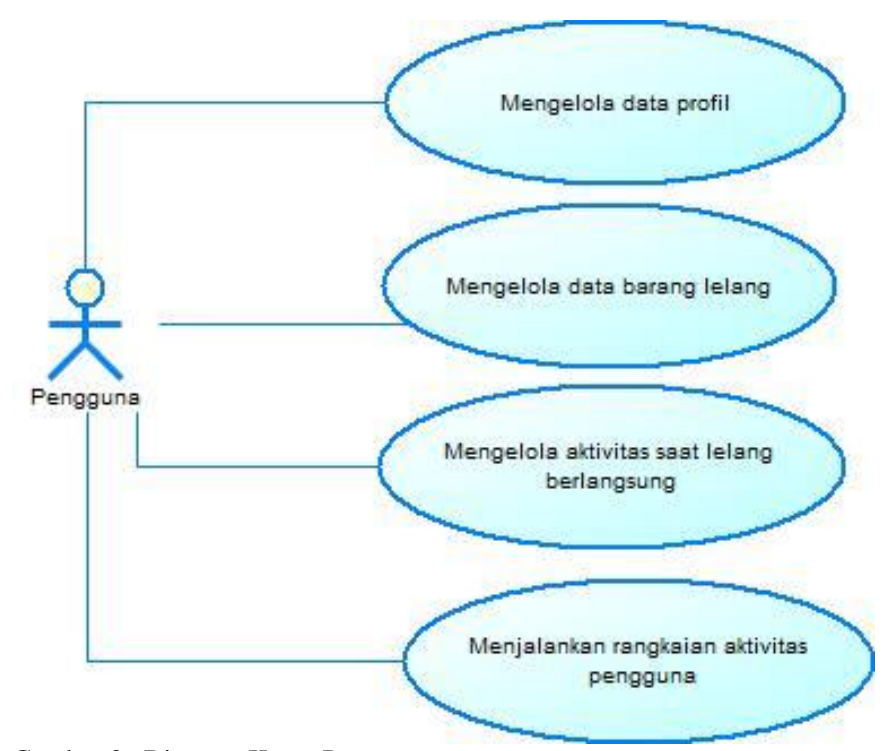

Gambar 3. Diagram Kasus Penggunaan

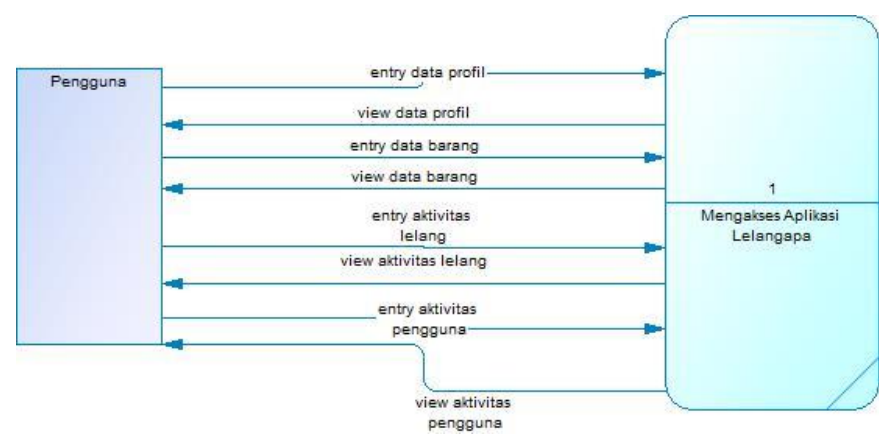

Gambar 4. Diagram Alir Aplikasi
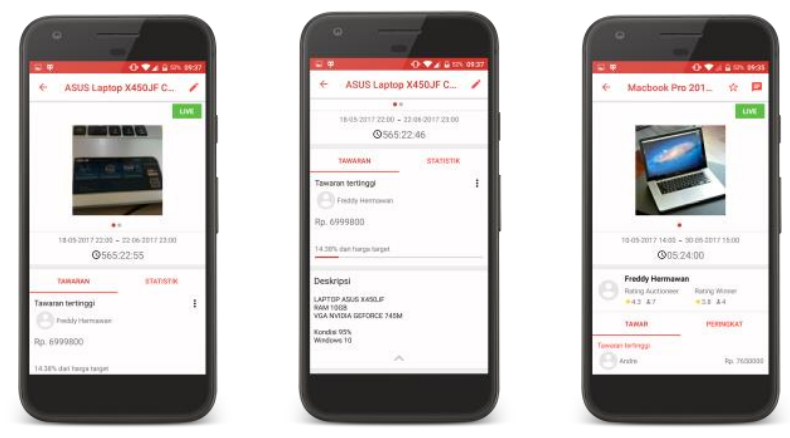

Gambar 5. Tampilan Halaman Detail Barang pada Aplikasi

Pengguna dari aplikasi adalah masyarakat Indonesia dari semua kalangan dan semua usia.

\section{PENGUJIAN}

\section{A. Pengujian Fungsionalitas}

Pengujian fungsionalitas dilakukan dengan menggunakan metode black-box, yaitu membuat skenario-skenario uji coba per fungsionalitas yang telah dibuat. Berdasarkan pengujian fungsionalitas yang telah dilakukan, aplikasi telah lulus dari semua skenario pengujian.

\section{B. Pengujian Berbasis Responden}

Pengujian berbasis responden dilakukan untuk mengukur kepuasan pengguna saat menggunakan aplikasi. Terdapat enam pertanyaan bersifat ulasan dengan jawaban dari nilai 1-5 (tidak puas - sangat puas). Berdasarkan hasil dari pengujian berbasis responden yang dilakukan, penguji relatif puas, ditunjukkan dengan jawaban 4 (puas) yang mendapatkan jumlah jawaban tertinggi dengan $40.00 \%$, diikuti dengan jawaban 3 (cukup) dengan $33.00 \%$, dan jawaban 5 (sangat puas) dengan $23.33 \%$.

Tabel 1.

Hasil Pengujian berbasis Responden

\begin{tabular}{|c|c|c|c|c|c|c|}
\hline \multirow{2}{*}{ No. } & \multirow{2}{*}{ Pertanyaan } & \multicolumn{5}{|c|}{ Penilaian } \\
\hline & & 1 & 2 & 3 & 4 & 5 \\
\hline 1 & Tampilan aplikasi secara fisik & 0 & 0 & 1 & 3 & 1 \\
\hline 2 & $\begin{array}{l}\text { Aplikasi memiliki tampilan yang } \\
\text { mudah dimengerti dan dipelajari }\end{array}$ & 0 & 0 & 2 & 2 & 1 \\
\hline 3 & Aplikasi mudah digunakan & 0 & 0 & 3 & 2 & 0 \\
\hline 4 & $\begin{array}{l}\text { Pengguna dapat mengetahui } \\
\text { setiap fitur pada aplikasi dengan } \\
\text { mudah }\end{array}$ & 0 & 0 & 3 & 2 & 0 \\
\hline 5 & $\begin{array}{l}\text { Performa keseluruhan aplikasi } \\
\text { saat dijalankan di perangkat } \\
\text { milik pengguna }\end{array}$ & 0 & 1 & 0 & 1 & 3 \\
\hline 6 & $\begin{array}{l}\text { Aplikasi dapat memberikan } \\
\text { alternatif baru untuk jual beli } \\
\text { barang. }\end{array}$ & 0 & 0 & 1 & 2 & 2 \\
\hline & Total & 0 & 1 & 10 & 12 & 7 \\
\hline & Persentase $(\%)$ & 0 & 3.33 & 33.33 & 40.00 & 23.33 \\
\hline
\end{tabular}

\section{KESIMPULAN/RINGKASAN}

Dari hasil pengamatan selama proses perancangan dan hasil uji coba yang dilakukan, diambil kesimpulan sebagai berikut.

1. Aplikasi Lelangapa dapat memberikan pilihan baru bagi jual beli barang dengan sistem lelang yang diusung. Aplikasi telah dibangun berdasarkan kebutuhan yang ditetapkan dan memiliki fitur inti lelang yang interaktif dan pengembangan dari sistem lelang yang sesungguhnya, serta dapat dikembangkan lebih lanjut.

2. Berdasarkan hasil pengujian dengan responden, aplikasi Lelangapa dapat diterima dengan baik oleh kalangan umum, dengan 63\% dari jawaban kuesioner yang masuk mengatakan puas, dan $33 \%$ mengatakan cukup.

Pengembangan yang dapat dilakukan berikutnya adalah mengembangkan fitur escrow atau rekening bersama untuk menangani masalah transaksi, memperbaiki performa dari beberapa bagian pada aplikasi, menambah kapasitas server yang digunakan untuk kebutuhan scaling, dan mempublikasikan aplikasi ke khalayak umum secara bertahap. 


\section{UCAPAN TERIMA KASIH}

Terimakasih kepada Tuhan YME, atas segala karunia yang telah diberikan, kepada Bapak Rully Soelaiman, S.Kom., M.Kom., Bapak Rizky Januar Akbar, S.Kom., M.Eng., atas bimbingan dan dukungan yang telah diberikan selama pengerjaan, kepada teman-teman, keluarga, dan kerabat yang telah membantu memberikan doa, semangat, dan masukan selama pengerjaan.

\section{DAFTAR PUSTAKA}

[1] Y.-F. Kuo, S.-T. Yen, and L.-H. Chen, "Online auction service failures in Taiwan: Typologies and recovery strategies," Electron. Commer. Res. Appl., vol. 10, no. 2, pp. 183-193, Mar. 2011.

[2] "Bisnis Lelang (Auction) | Teori dan Perilaku Organisasi." [Online]. Available: http://perilakuorganisasi.com/bisnsi-lelang-auction.html. [Accessed: 17-Jul-2017].

[3] “Lelang," Wikipedia bahasa Indonesia, ensiklopedia bebas. 29-Mar2017.

[4] "Online marketplace," Wikipedia. 08-Jul-2017.

[5] "Buyer Tutorial." [Online]. Available: http://pages.ebay.com/globaltrading/buyer/index.html. [Accessed: 17Jul-2017].
[6] "Seller fees \& invoices." [Online]. Available: http://pages.ebay.com.au/help/sell/seller-fees.html. [Accessed: 17-Jul2017].

[7] "Lelang - Direktorat Jenderal Kekayaan Negara, Kementerian Keuangan Republik Indonesia." [Online]. Available: https://www.lelangdjkn.kemenkeu.go.id/. [Accessed: 17-Jul-2017].

[8] J. Zhang, "The roles of players and reputation: Evidence from eBay online auctions," Decis. Support Syst., vol. 42, no. 3, pp. 1800-1818, Dec. 2006.

[9] I. Sommerville, Software engineering. [Textbd.]. Addison-Wesley, 1989.

[10] N. Babich, "Mobile Design Best Practices," UX Planet, 14-Nov-2016. [Online]. Available: https://uxplanet.org/mobile-design-best-practices2d16d37ecfe. [Accessed: 14-Jul-2017].

[11] "Facebook Live auctions come to Singapore." [Online]. Available: https://www.techinasia.com/singapore-facebook-live-auctions. [Accessed: 15-Jul-2017].

[12] "99.6 percent of new smartphones run Android or iOS - The Verge." [Online]. Available: https://www.theverge.com/2017/2/16/14634656/android-ios-marketshare-blackberry-2016. [Accessed: 14-Jul-2017].

[13] D. Reisinger, "Apple and Samsung Stumble as Smartphone Market Soars," $\quad$ Fortune. [Online]. Available: http://fortune.com/2017/05/23/apple-iphone-gartner-market-share/. [Accessed: 14-Jul-2017]. 